\title{
Coherence in Cross-Sectoral Policies is Imperative For Sustainable Management of Ecosystems
}

\author{
Gouri S Joshi, Erach Bharucha
}

\begin{abstract}
Sustainable management of ecosystems is a priority concern for biodiversity conservation and climate change resilience. India has enacted various policies and statutes governing natural resources that form an integral part of ecosystem governance. The federal structure of India's governance confers the power on vertical (three layers of government) and horizontal (various ministries, departments of government) sectors, to legislate on a variety of environmental issues. Under the Constitution of India, subjects related to the protection of the environment, conservation of biological diversity are governed by the Union List; while subjects of water and land are governed by the State List. Subjects concerning forest and wildlife are governed by the Concurrent List of Schedule VII.
\end{abstract}

Implementation of statutes, governing different environmental subjects, is done by various ministries and departments including local self-governments established by 73rd and $74^{\text {th }}$ Constitutional Amendment Act, 1976. Activities programmes or projects. As the ecosystem management is a major sector of biodiversity management, the schemes are divided into core and congruent sectors and related sectoral plans.

Nexus approach is used to understand the importance of interlinks in the resource governance of India. This research work is ascertaining that conventional fragmented and isolated approach for governance of natural resources is detrimental to the sustainable management of ecosystems. On the background of climate change and increasing international cooperation for sustainable development, attaining coherence in the cross-sectoral policies governing ecosystem management is imperative.

Keywords: cross-sectoral policies, nexus approach, ecosystem management, coherence.

\section{INTRODUCTION}

In 2015 the United Nations adopted sustainable development as an agenda to be achieved by 2030. This agenda has 17 sustainable development goals (SDGs) with several targets to eradicate poverty and hunger, to halt the

Revised Manuscript Received on February 06, 2020.

* Correspondence Author

Gouri S Joshi*, Research Scholar, Bharati Vidyapeeth Institute of Environment Education and Research, Pune, India.

Email: gauphd@gmail.com

Dr Erach Bharucha, Director, Bharati Vidyapeeth Institute of Environment

Education and Research, Pune, India.

Email: bharucha.eracha.k@gmail.com defined in the policies are implemented through schemes, plans,

loss of biological diversity, to protect marine and terrestrial ecosystems and to provide justice and equality to global citizens through National programmes. Adoption of SDG was done to improve from the lessons learnt from the millennium development goals (MDGs) and to be resilient to implications of Climate Change. SDGs are highly ambitious and thus not always provided strategic methods to integrate it with other goals while implementing a particular SDG. Whether the implementation of one SDG adversely impacts the implementation of other SDGs is a matter of research Boas, I, Biermann F \& Kanie N think that these Goals do not effectively address all the concerns of sustainable development in an integrated way and thus have adverse implications [1].

Apart from the complexities and difficulties involved in the implementation of the SDGs, each party state is working to further the ground level achievement of these goals through policies and laws [2]. Various authors and researchers have discussed in details that policy integration of various sectors is the most preferred approach to be taken for achievement of the sustainable development goals, [3], [4], [5], [6], [7], [8], [9], [10], [11], [12], [13]. Literature review leads towards a need for understanding the linkage between various sectors such as land, land use planning, water, food, energy, business and development to reduce poverty, hunger, exploitation of resources, conservation of ecosystems towards the overall need for sustainable development. This conclusion is common even though researchers are adopting approaches such as environmental policy integration [14], [15], [16], [17], [18]; cross-sectoral policy coherence (recognised in Rio Declaration, 1992 Agenda 21 Chapter 8) [19], [20], [21]; ecosystem approach or 'integrated earth system' [22], [23]; nexus approach [24], [25], [26]; Gaia theory [27], [28], [29], [30].

In the recent past, nexus approach while studying in food security, water, land and energy, has received a wide acceptance at the international level [31], [32], [33], [34], [35]. This approach can also be used to enhance the linkages between diverse sectors such as corporate, mining, transport, biodiversity, forest sectors, which are currently operating in isolation. Integrated approach in governance of natural resources is essential to reduce the adverse impacts of one policy over other governing different natural resources. Policymakers have to play a crucial role in the implementation of SDGs by adopting an integrated policy approach [36], [37], [38], [39]. An age-old Indian concept of "Vasudhaiva kutumbakam" encompasses all previously stated approaches by

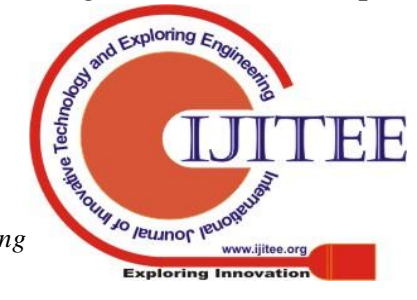


accepting that all-natural component of the earth belong to one single-family and thereby are interlinked and interdependent [40], [41], [42].

Sustainable management of ecosystems is essential for healthy ecosystems, protection of the environment, social wellbeing, sustainable development and overall welfare of the human being [43]. Devoid of human intervention, the ecosystem is a self-sustainable entity having close coordination with other ecosystems. Due to overuse of ecosystem services and natural resources, the equilibrium of these ecosystems is de-stabilising and therefore it becomes vital to regulate and conserve ecosystems [44]. Ecosystem services are the basis of livelihood generation and thus global economics [45]. Ecosystem management is by far considered to be an administrative function which governs the rights and duties of various stakeholders towards ecosystem services [46]. Therefore, SDGs explicitly recognize the need for appropriate laws and governance of resources along with a local cultural system to achieve the intended agenda. To deal with the sustainability, there is a need for new legal solutions and strategies which can balance the social, economic, ecological, political and environmental rights of people. The recent global assessment of environmental rule of law 2019 [47] states that after the 1970s most of the countries of the world have enacted frameworks for protection and improvement of the environment but the implementation of these laws remained poor [48]. The world community also recognizes the complexities associated with the cross-sectoral approach taken for policy development at the national level and expects that better policy coherence is essential to deal with the forthcoming challenges associated with climate change and environmental degradation [49], [50], [51] [52].

It is essential to understand the policy reflections in India and its overall coherence level while addressing SDGs. Our insights into education for sustainable development (ESD) shows that as SDGs are created for governance by nation-States, they do not translate into ground-level communication, education and public awareness institutions, as this involves multi-sectoral contributions associated with locally relevant government bodies, their schemes and programmes [53]. The policy development in India is distributed between vertical and horizontal sectors bringing multiple stakeholders in the process. Most national policies of India developed for protection and conservation of natural resources and utilization of natural resources were adopted at different times with different objective. It is essential to understand whether all these multi-sectoral, multi-stakeholder policies express cohesive agenda or work with a fragmented approach. Integration of competing claims of multiple sectors and bridging the gap between intention and implementation is the need of an hour [54]. Recently, while adopting national policies and action plans, the Government of India has started expressing the need for policy integration [55]. Chennai flood (2015), Kerala flood (2018), the water crisis in major cities of India (2019), drought in Marathwada region while destructive floods in other parts of Maharashtra (2019) such incidences highlight increasing impacts of climate change at a local level. It is estimated that climate change will further intensify droughts [56] and flooding due to excessive monsoon and cloud bursts across the region of India [57], [58], adversely impacting biological diversity, pushing many species towards extinction. The lack of preparedness and resilience towards climate change is detrimental for the efficient implementation of SDGs. In such a situation comprehensive planning for conservation of ecosystems through precautionary principle and integration of pro-environmental action strategies through coherent cross-sectoral policies is imperative.

India has a Quasi-federal structure of governance wherein the power to govern various natural components are divided between Central, State and local governments. Schedules VII, XI and XII of the Constitution of India provides lists of subjects to be covered by the Central Government, State Governments, issues collectively decided by the Centre-State and subjects governed by the Local Self Governments. Eleventh and Twelfth Schedules were added in the Constitution of India as a part of the Panchayat Raj system of governance that expect rural and urban governance centres to work with strong stakeholder participation. However, the acceptance and approval of Central and State policies for the governance of various natural resources and ecosystems took place at different times and in diverse environmental and political situations. Many of the policy frameworks established in the past are still operational and do not always match with newly accepted strategies. In the light of a changing international approach towards integration, management and governance of ecosystems, it is essential to study India's policy approach towards a sustainable conservation of ecosystems.

This study aims at mapping the jurisdictions of vertical and horizontal sectors over ecosystems of India and to understand the policy nexus of different sectors for sustainable management of ecosystems. This result is then used to analyse national-level policy coherence for sustainable management of ecosystems for achieving SDGs such as (SDG 14 - life below water and SDG 15 - life on earth). Both these goals pertain to maintaining biodiversity and sustainable management of ecosystems.

The aim of this study finds support from the National Biodiversity Action Plan (NBSAP) and Intended Nationally Determined Contributions (INDC). Action points of the National Biodiversity Action Plan 2008 as collected in compendium of 2014, states in point number eight, clause number 133, that a 'review of the body of existing legislation relevant to biodiversity conservation, to develop synergies among relevant statutes and regulations, eliminate obsolescence, and amalgamate provisions with similar objectives, in line with national environmental policy'. Further, to encourage and facilitate a review of legislation at the level of state and local governments to ensure their consistency with this policy'. Point 4.11 of the Draft National Forest Policy recognises the need to harmonise the National Forest Policy with other policies and laws that govern and other resources.

\section{RESEARCH METHODOLOGY:}

Three stages are involved in this research work. The first stage of the study covers policy survey to identify a set 
of national-level policies governing various components of ecosystems such as water, air, land, forests, wildlife and biological diversity. Jurisdiction mapping and analysis of relevant national policies governing water, air (climate), land, the forest along with biodiversity was done to understand the nexus between policies governing ecosystem management and other policies governing various components of an ecosystem.

At the second stage, contextual analysis of the policy documents was done to identify relevant national-level policies specifically essential for 'sustainable management of ecosystems'. These policies were compared with each other and method of Qualitative Document Analysis (QDA) was used with a scoring system to understand implications of the policy text (Altheide et al. 2008; England I M 2018). This scouring system was altered to suit the current study as has been elaborately stated in Table 1. Matthew I England and eight other researchers have used this method in their collective research to identify the extent and nature of climate change adaption in planning strategies for water and agricultural sector of policies for three countries Malawi, Tanzania and Zambia and to assess the policy coherence across the sectors, as well as with national development plans and climate change adaption policies and strategies. The same method has been used to understand coherence between various policies at the national level, that are essential in the sustainable management of various ecosystems in India and which are the basis for achieving several of the SDGs.

All the relevant policy documents published by the government of India for protection and conservation of ecosystems were selected for comparison. Use of internet searches what is done to locate the sector policies on government and other relevant websites. The policy text was analysed for the existence of words such as ecology, environment, ecosystem management, sustainability, environmental concerns, and environmental sustainability.

The focus of the study is on sustainable management of ecosystems and to understand the nexus and coherence of national policies adopted immediately before and after acceptance of Agenda 2030 i.e. SDGs. Identified National Policies were analysed based on the content analysis and/or paragraph included in the policies providing specific background, context and insights. Scoring criteria used for assessment of coherence has been adopted from the studies done by Le Gouais and Wach (2013) and England, Matthew I., et al (2018).

Table 1: Scouring system

\begin{tabular}{|l|l|l|}
\hline $\begin{array}{l}\text { Type of } \\
\text { coherence }\end{array}$ & Description of coherence & $\begin{array}{l}\text { Sc } \\
\text { ore }\end{array}$ \\
\hline $\begin{array}{l}\text { High } \\
\text { coherence }\end{array}$ & $\begin{array}{l}\text { The policy alliance is strongly linked to other policy } \\
\text { statements. The policy gives specific attention to the } \\
\text { sustainable management of ecosystems while using } \\
\text { the resource. It includes numerous convergence } \\
\text { opportunities through strategies aspects and action } \\
\text { plans. }\end{array}$ & 3 \\
\hline $\begin{array}{l}\text { Partial } \\
\text { coherence }\end{array}$ & $\begin{array}{l}\text { Although the policy supports the sustainable } \\
\text { management of the ecosystem, integration of the } \\
\text { policy with other sectors is fuzzy, essentially } \\
\text { unclear. }\end{array}$ & 2 \\
\hline $\begin{array}{l}\text { Limited } \\
\text { coherence }\end{array}$ & $\begin{array}{l}\text { management of ecosystems but does not provide } \\
\text { details on actionable points. }\end{array}$ & 1 \\
\hline
\end{tabular}

\begin{tabular}{|l|l|l|}
\hline $\begin{array}{l}\text { No } \\
\text { coherence }\end{array}$ & $\begin{array}{l}\text { No statement concerning coordination or sectoral } \\
\text { alignment is articulated for sustainable management } \\
\text { of ecosystems. }\end{array}$ & 0 \\
\hline
\end{tabular}

\section{RESULTS AND DISCUSSION:}

Constitution of India has expressed provisions under Article 48A 'Directive Principles of State Policy', making the States responsible for protection, preservation and improvement of the environment. The Article further mandates that the States should safeguard the forests and wildlife of the country. Similar responsibility has also been cast upon the citizens of India, under the concept of 'Fundamental Duties' (Article $51 \mathrm{~A}(\mathrm{~g})$ ) to protect and improve the natural environment including forests, lakes, rivers, wildlife and expects a compassionate treatment to living creatures. Various vertical and horizontal agencies of the governments at Central, State or local level and citizens of India would be able to execute their responsibilities only when the education, training and work culture supports Constitutional agenda of environment protection, through National and State policies. The policy in India is responsible to develop various plans, programmes, and schemes through which respective governments allocate funds for the execution of the projects eligible under the schemes. The present study has analysed 12 national-level policies covering various sectors to understand nexus and coherence between these national-level policies.

All these policies have overlapping nexus with various resources, as the earth is one ecosystem. Awareness about present environmental conditions, its impact on human existence and activities to be carried out to increase the societal resilience against climate change is largely dependent on the penetration of environmental education at the grass-root level. Essentially, National Education policy should eternalize the agenda and provide a mechanism for implementation of the same. Such a policy of the government has direct linkage/ correlation/ nexus with social and environmental wellbeing, decision-making capacity of the society and robust governance of the resources. The National Health Policy needs to address the prominent causes of the deterioration of social health. Environmental degradation, natural calamities, water \& air pollution, have direct impacts on social health which should reflect through health-related policies [62]. The vulnerability of society due to poverty, illiteracy has a direct impact on resource exploitation [63]. Increasing standard of living demands more and more energy consumption and infrastructure development to reduce hunger, poverty and illiteracy [64]. If sustainable practices and ecosystem management are overlooked in the quest of achieving no hunger, no poverty, the carrying capacity of all the ecosystems would be compromised. This may further lead to water and land scarcity pushing the world far away from food security. The discussion leads us towards an obvious conclusion to acknowledge the nexus between multiple sectors which have interdependence over multiple natural resources and thereby interconnection with several sectors.

The nexus approach is widely accepted as the basis for demanding better coherence in the cross-sectoral policies related to water, food and energy sectors. The purview of this approach needs to be 
enlarged to encompass environment, ecology, economy and health sectors. Coherence in policy-making, action plans, implementation strategies and legislation is highly imperative to have a holistic implementation of SDGs.

Sustainable ecosystem management is the key to achieve equilibrium in the natural processes and therefore carrying capacity of the given ecosystem should be considered as a most essential factor while developing implementation or development plan under any policy in a particular bio-geographic zone.

Out of all the policies and action plans analysed, environment conservation policies and action plans have shown the greatest cross-thematic coherence; whereas, Water policy, 2012 has reflected partial coherence with SDG 14 and SDG 15. Tourism is known for negative impacts on the environment and ecosystem equilibrium as the sector brings all types of pollution, habitat fragmentation and resource exploitation with it [65]. Unfortunately, the Draft National Tourism Policy is not expressing enough concerns for reducing or mitigating the adverse impacts on the environment. The intensity of coherence and available opportunity to have cooperation with other fields like Integrated Watershed Management, forestry, wildlife and biodiversity is almost absent. In a couple of paragraphs, the policy merely discusses the revenue potential of the pristine areas, without discussion or guidelines for responsible tourism. The current trend of eco-tourism, nature-friendly tourism, agrotourism has not been covered sufficiently.

Greater integration of communication, education, and public awareness (CEPA) in the implementation of policies and institutional capacity building were felt essential. Health policy has shown almost no opportunity for coordination and integration with cross-sectoral policies.

Table 2: Extent of cross-sectoral policy coherence for sustainable management of ecosystems

\begin{tabular}{|c|c|c|c|c|c|}
\hline $\begin{array}{c}\text { Sr } \\
\text { No }\end{array}$ & Policy & $\begin{array}{c}\text { High } \\
\text { coherence }\end{array}$ & $\begin{array}{c}\text { Partial } \\
\text { coherence }\end{array}$ & $\begin{array}{c}\text { Limited } \\
\text { coherence }\end{array}$ & $\begin{array}{c}\text { No } \\
\text { coheren } \\
\text { ce }\end{array}$ \\
\hline 1 & $\begin{array}{c}\text { National Education } \\
\text { Policy, 2019 }\end{array}$ & & 2 & & \\
\hline 2 & $\begin{array}{c}\text { Draft National Forest } \\
\text { Policy 2018 }\end{array}$ & 3 & & & \\
\hline 3 & $\begin{array}{c}\text { National Health Policy, } \\
2017\end{array}$ & & & & 0 \\
\hline 4 & $\begin{array}{c}\text { Draft National Energy } \\
\text { Policy, 2017 }\end{array}$ & & & 1 & \\
\hline 5 & $\begin{array}{c}\text { National Wildlife Action } \\
\text { Plan 2017 - 2031 }\end{array}$ & 3 & & & \\
\hline 6 & $\begin{array}{c}\text { National Plan for } \\
\text { Conservation of Aquatic } \\
\text { Ecosystems, 2016 }\end{array}$ & 3 & & & \\
\hline 7 & $\begin{array}{c}\text { India's Intended } \\
\text { Nationally Determined } \\
\text { Contributions, 2015 - } \\
2030\end{array}$ & & 2 & & \\
\hline 8 & $\begin{array}{c}\text { Draft National Tourism } \\
\text { Policy, 2015 }\end{array}$ & & & & \\
\hline 9 & $\begin{array}{c}\text { National Biodiversity } \\
\text { Action Plan Addendum } \\
2014\end{array}$ & 3 & & & \\
\hline 10 & $\begin{array}{c}\text { Draft National Land Use } \\
\text { Policy, 2013 }\end{array}$ & & 2 & & \\
\hline 11 & $\begin{array}{c}\text { National Water Policy, } \\
2012\end{array}$ & & & & \\
\hline & & & & \\
\hline
\end{tabular}

A) National Education Policy, 2019: Sustainable management of the ecosystem has not been addressed specifically in the National Education Policy, 2019. The policy expresses the concerns about localised education in local language and an action plan to incorporate multi-disciplinary subjects knowing ecology, zoology and environmental sustainability. The text analysis reflects that the terms ecology, environmental sustainability and sustainable development have been used in the policy to address the environmental issues. The policy is silent about addressing and incorporating correlation between ecosystem management, livelihood generation, health, education and environmental sustainability. The component of water conservation has been addressed under chapter 20 'vocational education' point 20.6 with title 'areas of special focus' and point 21.1 'developing curriculum for adult education'. The subject of forestry and agroforestry has been inserted in the professional education criteria under chapter 16. The subject of wildlife conservation has a passing reference in chapter 20 under the discussion 'special focus on tribal areas' when the subject should have larger recognition all over India and not restricted to the tribal areas. Overall, the policy has partially recognised the importance of sustainable management of ecosystems and at many instances has expressed the need and mechanism for establishing coherence with other policies. The policy does not have a special chapter or specific instructions for integration of environmental issues and aspects of sustainable management of ecosystems as has been expected under the ESD programme [59] or National Biodiversity Strategy and Action Plan, whereby micro-lever action strategy would be implemented with a greater impact [60]. The policy is not giving any adherence to CEPA i.e. communication, education and public awareness, in its internationally acknowledged form. Reference to environmental conservation and understanding natural environment for research, development, education has been taken into consideration. But expressed reference to SDG 14 and 15 is not considered while addressing SDG4.

B) The Draft National Forest Policy, 2018: The draft policy states that the previous forest policy of 1988 successfully increased the forest cover while subordinating direct economic benefits to maintain ecological balance. The policy express need for higher coherence while promoting biodiversity conservation, soil conservation, promoting rural agroforestry and urban greens, forest management for water recycling and increasing stakeholder participation while addressing economic perspective of forests such as production forestry (4.2.1 of policy), valuation of forests (point 4.2.2 of policy) and facilitation of forest industry interface (point 4.4 of policy). The policy has given a higher focus on education and research for the integration of climate change and wildlife management (point 4.5 of the policy). This policy has expressed good coherence with other policies and programmes in India recognising the importance of integration of legal and institutional framework, training and skill 
development, harmonisation of the policy with other policies and assimilation of international commitments.

Even when the policy is addressing the aspect of sustainable management of ecosystem and is coherent with other policy documents recognising the need for integration of other policies; the policy does not provide the actionable points for implementation of this overarching agenda and strategy. Further, the policy is completely silent about the grasslands and other forest types and does not deal with the issue of the definition of 'forest' based on dictionary meaning or canopy cover [61].

C) Draft National Energy Policy, 2017 (by NITI Aayog) (NEP): The policy is focussing on demand and supply side of energy while planning to achieve emission reduction targets as having been kept in India's Intended Nationally Determined Contributions (INDC) (point 1.2 of NEP). The policy accepts the ill-effects of the coal mining on the local environment, ecology and people and looks forward to having a mechanism to share the sovereign income with local bodies to improve the standard of living of the people and ecosystem management. The interaction of the power sector with fuel supply, land allocation, financing and environmental clearance is mentioned in the policy; but discussion on mitigation of impacts on the ecosystem due to this sector is missing from the policy. The coherence of this policy with other sectoral policies has been recognised in the policy (Point 14. 3 of the policy) but the mechanism to achieve the same has not been discussed. The policy includes the concerns of air pollution, clean energy development and promoting green and renewable energy sector but is completely silent about sustainable development goals, biodiversity conservation and sustainable management of ecosystems. The entire concern of the policy is restricted to 'environmental clearance' and did not go beyond that directly. Term conservation has been used frequently but the context is energy conservation and not ecological or environmental conservation. This policy reflects limited coherence with other national policies and does not discuss sustainable ecosystem conservation either directly or indirectly.

D) Draft Health Policy, 2017: The policy does not appreciate the contribution of degraded environmental conditions in increased health problems. Four reasons cited for bringing out the new draft for National Health Policy do not have to change climatic conditions or degradation of ecosystems as one of the reasons. The policy in its goals recognises the role of SDGs and states that implementable targets aligned to these goals have been identified and listed. the Policy while addressing preventive and promotive health (point 3.2 of the policy) identify 'Swatch Bharat Abhiyan' and indoor and outdoor pollution as priority areas for establishing better coordination but do not recognise the role of ecosystem equilibrium for access to healthy and nutritious food and water. The role of better waste management is recognised only at two junctures urban health care determinants (point 3.3.5 of the policy) and public health care management cadre (point 11.8 of the policy). An elaboration on disaster management fails to recognise the changing climatic conditions and a probable increase in the frequency and intensity of natural calamities. The entire policy intends to have coherence within the sector of social and family health but does not deal unequivocally with a need for coherence in multi-sectoral policies and laws. Recognition to the sustainable management of ecosystems or a role of biodiversity and the need for protection of it for the better health of communities has not been acknowledged even remotely.

E) National Wildlife Action Plan 2017-2030 (NWAP): The sector is governed under the National Environment Policy, 2006 (NEP). Current NWAP is the third revision of the earlier NWAP - I 1983 and then of NWAP - II 2002. The stated objective of current NWAP is to strengthen the protected area network with improved technology, completing demarcation and rationalisation of the boundaries and to compensate the affected people due to the creation of protected areas. The action plan also aligns itself with AICHI biodiversity targets and the National Biodiversity Action Plan (NBAP). The plan takes into account the impact of climate change and need for protection and conservation of biodiversity while doing sustainable use of it, but do not address the impacts of urban area spill-over the wilder areas and associated problems such as responsible waste disposal, restrictions on water consumption and forest area diversions. The action plan aptly discusses the role of biodiversity conservation and ecosystem management in disaster mitigation and social wellbeing. Essential actionable activities have been inserted for having coherence with laws and policies rights of forest communities, their livelihood opportunities, role of local self-governments, and stakeholder participation in resource management, disaster mitigation, bringing changes in environmental clearance process for energy, transport and spatial development projects (page 100 of the plan under 'Actions Required'). The plan is trying to explore possibilities for enhanced cooperation and coordination between local committees and institutions established under various laws and schemes (page 74 of the plan). In chapter XIII the plan also accepts that the coastal areas, water bodies, biodiversity and various components of ecosystem management are governed under different sectoral policies and laws, thereby creating hindrance in holistic approach (page 89 of the plan). It takes into account the importance of education and enhancement of forest and ecological management aspects for better integration with other sectors. The NWAP is also providing a period within which certain targets to be achieved for wildlife protection and strengthening of protected area network. Overall the action plan is having grater coherence with integrated forest and wildlife management plans, right settlement objectives and incorporation of local institutions in the execution of the plan.

F) National Plan for Conservation of Aquatic Ecosystems 2017 (NPCAE): This action plan for the conservation of Aquatic ecosystem has leapt forward by providing in detail requirements for the development of implementation projects and providing formats and templates for keeping the record of actions and expenditures. The plan provides for the guidelines to develop a management plan for different aquatic ecosystems (page 2 of the plan). The plan intends to bridge the gap between ecosystem protection requirements and capacity, knowledge, skills of available

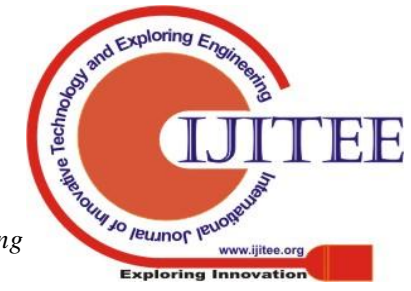


human resource and to include the focus on the entire water drainage management. The plan discusses the prohibitions to be imposed on solid waste disposal, wastewater treatment, irrigation and industrial discharges. The plan is bringing in CEPA through promoting visitors' centre, information booklets, and information centres and acknowledges the need for resources to facilitate knowledge and capacity building for sustainable ecosystem management (page 38 of the plan). The plan has also given the list of congruent schemes under other sectors and the way to achieve integration of these schemes.

G) India's Intended Nationally Determined Contributions (INDC): Highly appreciated and ambitious INDCs recognise the importance of sustainable management of ecosystems and emphasise on protecting biological diversity and Himalayan ecosystem. The imposition of cess on coal has been initiated to develop a fund essential for protection and management of ecosystems and biodiversity (page 27 of the document). At the same time fund allocation has also been done by creating a separate pool for climate adaption combat by sectors such as agriculture, forestry, water resource etc. Various strategies for fund generation and bringing efficiency in the energy sector through technological advancement have been mentioned along with actionable activities. The document is trying to bring concurrence in various sectoral policies similar to waste disposal, forestry enhancement, transport efficiency, climate-resilient infrastructure, reducing the vulnerability of poor, health and safety, green energy, coastal management, water mission etc. The document takes an overview of most of the policies and laws, enacted for the protection and improvement of environment and human wellbeing and is trying to link them together with the National Green Mission with actionable points. Even then, the document is not providing clear insight as to how to bring the coherence when it comes to the implementation of all these sectors having nexus for the common goal of sustainable development. The document is succinct in providing mandates for sustainable management of ecosystems throughout India and not merely for the Himalayan ecosystem.

H) Draft National Tourism Policy, 2015: The policy document is published to renovate the earlier National Tourism Policy, 2002. Seven key areas identified by tourism policy Swagat (Welcome), Soochana (Information), Suvidha (Facilities), Suraksha (safety), Sahayog (Cooperation), Samarachana (Infrastructure development), Safai (Cleanliness) does not include Sansadhan Sanvardhan Resource Conservation) as a paramount necessity. The policy conveys its concerns about changing climate and negative impacts of tourism on environmental sustainability (page 9 of the policy). The mission statement in the policy covers environmental sustainability along with social, cultural and economic sustainability while promotion of tourism activities (page 10 of the policy). The policy while discussing the availability of suitable land for tourism near dams, rivers and backwaters fail to discuss the adverse impacts of such a development on the ecosystem, and probable care and mitigations measures to be adopted during and after the development. No reference has been given to SGD 12, SDG 14 and SGD 15. The entire policy nowhere expresses the requirement of sustainable management of ecosystems while promoting tourism. The policy discusses the tourism requirements and potential from a revenue generation point of view and does not identify linkages and essential collaborations required for the policy with other sectors to achieve sustainable development.

I) National Biodiversity Action Plan, 2014 (Addendum) (NBAP): India is known for its proactive nature conservation efforts in spite of having huge developmental pressures with $2^{\text {nd }}$ largest population of the world. The NBAP recognises the importance of biodiversity as a cornerstone of the resilient and self-sustainable ecosystem. The plan not only promotes sustainable ecosystem management but is also adopting strategies to restore and rehabilitate the ecosystems to its natural capacity (page 11 of the addendum). A specific emphasis has been given for integration of biodiversity concerns in other social and economic development sectors. National Biodiversity Targets specifically correlate themselves with Aichi Biodiversity Targets and SDGs with precise attention to the sustainable management of ecosystems. NBAP provides numerous opportunities with indicators for coherent implementation through which agenda kept by the respective policies can be achieved through the existing institutional setup. NBAP has provided a clear vision and plan for mainstreaming biodiversity conservation and sustainable management of ecosystem in all the other social and economic sectors. For the sake of the record, it is essential to mention that NBAP has too many objectives with too many indicators thereby making it difficult to prioritise the actions for sustainable management of ecosystems.

J) Draft Land Use Policy, 2013: While discussing about the definition of the 'land use planning' as has been provided by United Nations Food and Agriculture Organisation (FAO) and United Nations Environment Programme, the policy accepts that the process of land use planning is to balance environment and needs of people to achieve sustainable development. The policy recognises the threat potential of the haphazard development in the destruction of ecologically fragile and sensitive areas (page 3 of the policy). The policy solicits the attention towards impacts of fragmented implementation of water resource projects and cropping systems on land degradation and soil erosion (page 4 of the policy). This policy recognises all the inter-disciplinary aspects of land use associated with spilling over of urban cities on rural areas, need of industrialisation along with its impacts, needs for better transport and infrastructure facilities, conflicts involved in forest land and mining sector (page 11 of the policy) and expects higher coherence and integration of land use planning in all the other policies. The policy explicitly discusses the objectives of 'eco-sensitive zones' and need for sustainable management of water, forest, biodiversity and related forest, coastal zone, wetland ecosystems (page 15, 16 of the policy). Even though this policy recognises all the environmental, ecological and ecosystem management aspects, the guiding principles of the policy for national land utilisation do not include the terms such as sustainable development, ecosystem management, environmental sustainability etc. The policy acknowledges SDG 1, 2, 5, 10, 12 and 16 through guiding principles but do not acknowledge SDG 
13,14 , and 15 directly but incorporates the components of sustainable management of ecosystem through objectives and strategy. The policy inserts the need for harmonisation of the policy with existing policies and laws with its seventh principle.

K) National Water Policy, 2012 (NWP): National water policy is not directly having any reference to the sustainable management of the ecosystem but has framed the agenda to be more resilient to climate change. The concerns expressed in the policy include water-stressed conditions, sprawling urbanisation, sea-level changes due to climate change, increasing surface and groundwater pollution making it unavailable for utilisation, temporal and spatial variation in rainfall in different biogeographic zones and associated governance intricacies. It takes into consideration an important aspect of water pricing and inadequacy of state-level legal frameworks (point 7, page 7 and point 2 page 4 of the policy). The policy puts increasing stress on the water supply, sanitation, trans-boundary water disputes, inter-state river disputes, need for research, development, and data management but fails to provide any priority-based strategy. The policy is not providing essential opportunities for stakeholder participation and inter-sectoral coordination. The policy mentions about the integrated water resource management but is not inclusive enough to bring coherence in various sectors such as wildlife \& forest, biodiversity, agriculture, fisheries, animal husbandry, and education or CEPA.

L) National Environment Policy, 2006 (NEP): It's a comprehensive policy to identify different ecosystems, their importance, current pressures on those ecosystems, key challenges for conservation, action required for sustainable maintenance of the ecosystems, available legal frameworks. NEP, since 2006 is serving the purpose to float various schemes and programmes to achieve prescriptions for environment protection, biodiversity conservation and ecosystem maintenance. The policy amalgamates various dimensions such as education, health, disaster mitigation, traditional knowledge, livelihood dependence to augment the field of environmental sustainability. In the preamble, the policy takes the cognisance of all the previous policies to achieve coherence while defining viable action strategies.

\section{CONCLUSION:}

The analysis suggests that policy coherence for the sustainable management of ecosystems in cross-sectoral policies needs better harmonization for improved stakeholder coordination and cooperation. $41.66 \%$ of the policies compared reflect high coherence, $25 \%$ show no coherence, $16.67 \%$ of the policies show limited coherence, and $16.67 \%$ show no coherence with each-other for sustainable management of ecosystems. National Education Policy 2019 and National Health Policy 2017 do not appreciate ecosystem management as an integral or associated part of their objectives.

Integration of CEPA for effective implementation of action plans to achieve viable results in crucial. Policies of the similar or ancillary sector show better coherence whereas the policies which typically are not considered as ancillary to ecology and environment show partial or limited coherence. The SDGs categorically incorporate environmental, social and economic sector together to achieve the golden mean of sustainability. Cross-sectoral national policies need to reflect this coherent intention with feasible action points, whereby further programmes, schemes and administrative decision making would follow the footsteps of the sustainable management of ecosystems.

\section{REFERENCES}

1. Boas, I., Biermann, F. and Kanie, N., 2016. Cross-sectoral strategies in global sustainability governance: towards a nexus approach. International Environmental Agreements: Politics, Law and Economics, 16(3), pp.449-464.

2. Le Blanc, D., 2015. Towards integration at last? The sustainable development goals as a network of targets. Sustainable Development, 23(3), pp.176-187.

3. Pinkse, J. and Kolk, A., 2012. Addressing climate change-sustainable development nexus: The role of multistakeholder partnerships. Business \& Society, 51(1), pp.176-210.

4. Griggs, D., Stafford-Smith, M., Gaffney, O., Rockström, J., Öhman, M.C., Shyamsundar, P., Steffen, W., Glaser, G., Kanie, N. and Noble, I. 2013. Policy: Sustainable development goals for people and planet. Nature, 495(7441), p.305.

5. Griggs, D., Stafford Smith, M., Rockström, J., Öhman, M.C., Gaffney, O., Glaser, G., Kanie, N., Noble, I., Steffen, W. and Shyamsundar, P., 2014. An integrated framework for sustainable development goals.

6. Biermann, F., Stevens, C., Bernstein, S., Gupta, A. and Kabiri, N., 2014. Integrating governance into the sustainable development goals (No. 3). UNU-IAS.

7. Weitz, N., Nilsson, M. and Davis, M., 2014. A nexus approach to the post-2015 agenda: Formulating integrated water, energy, and food SDGs. SAIS Review of International Affairs, 34(2), pp.37-50.

8. Le Blanc, D., 2015. Towards integration at last? The sustainable development goals as a network of targets. Sustainable Development, 23(3), pp.176-187.

9. Boas, I., Biermann, F. and Kanie, N., 2016. Cross-sectoral strategies in global sustainability governance: towards a nexus approach. International Environmental Agreements: Politics, Law and Economics, 16(3), pp.449-464.

10. Boas, I., Biermann, F. and Kanie, N., 2016. Cross-sectoral strategies in global sustainability governance: towards a nexus approach. International Environmental Agreements: Politics, Law and Economics, 16(3), pp.449-464.

11. Gupta, J. and Nilsson, M., 2017. 12 Toward a Multi-level Action Framework for Sustainable Development Goals. Governing through Goals: Sustainable Development Goals as governance innovation, p. 275 .

12. Stafford-Smith, M., Griggs, D., Gaffney, O., Ullah, F., Reyers, B., Kanie, N., Stigson, B., Shrivastava, P., Leach, M. and O’Connell, D., 2017. Integration: the key to implementing the Sustainable Development Goals. Sustainability Science, 12(6), pp.911-919.

13. Stafford-Smith M, Griggs D, Gaffney O, Ullah F, Reyers B, Kanie N, Stigson B, Shrivastava P, Leach M, O'Connell D. Integration: the key to implementing the Sustainable Development Goals. Sustainability Science. 2017 Nov 1; 12(6):911-9.

14. Barrass, R. and Madhavan, S., 1996. European economic integration and sustainable development: institutions, issues and policies. McGraw-Hill.

15. Liberatore, A., 1997. The integration of sustainable development objectives into EU policy-making (pp. 107-126). Routledge: London.

16. Lafferty, W. and Hovden, E., 2003. Environmental policy integration: towards an analytical framework. Environmental Politics, 12(3), pp.1-22.

17. Runhaar, H., Driessen, P.P. and Soer, L., 2009. Sustainable urban development and the challenge of policy integration: an assessment of planning tools for integrating spatial and environmental planning in the Netherlands. Environment and Planning B: Planning and Design, 36(3), pp.417-431.

18. Aall, C., Dodds, R., Sælensminde, I. and Brendehaug, E., 2015. Introducing the concept of environmental policy integration into the discourse on sustainable tourism: a way to improve policy-making and implementation?. Journal of Sustainable Tourism, 23(7), pp.977-989.

19. Kardos, M., 2012. The reflection of good governance in sustainable development

strategies. Procedia-Social and Behavioral Sciences, 58, pp.1166-1173. 


\section{Coherence in Cross-sectoral Policies is Imperative for Sustainable Management of Ecosystems}

20. Nilsson, M., Zamparutti, T., Petersen, J.E., Nykvist, B., Rudberg, P. and McGuinn, J., 2012. Understanding policy coherence: analytical framework and examples of sector-environment policy interactions in the EU. Environmental Policy and Governance, 22(6), pp.395-423.

21. Di Gregorio, M., Nurrochmat, D.R., Paavola, J., Sari, I.M., Fatorelli, L., Pramova, E., Locatelli, B., Brockhaus, M. and Kusumadewi, S.D., 2017. Climate policy integration in the land-use sector: Mitigation, adaptation and sustainable development linkages. Environmental Science \& Policy, 67, pp.35-43.

22. Folke, C., Carpenter, S., Walker, B., Scheffer, M., Chapin, T. and Rockström, J., 2010. Resilience thinking: integrating resilience, adaptability and transformability. Ecology and Society, 15(4)

23. Schellnhuber, H.J. and Wenzel, V. eds., 2012. Earth system analysis: integrating science for sustainability. Springer Science \& Business Media.

24. Weitz, N., Nilsson, M. and Davis, M., 2014. A nexus approach to the post-2015 agenda: Formulating integrated water, energy, and food SDGs. SAIS Review of International Affairs, 34(2), pp.37-50.

25. Biggs, E.M., Bruce, E., Boruff, B., Duncan, J.M., Horsley, J., Pauli, N McNeill, K., Neef, A., Van Ogtrop, F., Curnow, J. and Haworth, B., 2015. Sustainable development and the water-energy-food nexus: A perspective on livelihoods. Environmental Science \& Policy, 54, pp.389-397.

26. Kurian, M., 2017. The water-energy-food nexus: trade-offs, thresholds and transdisciplinary approaches to sustainable development. Environmental Science \& Policy, 68, pp.97-106.

27. Lovelock, J. and Lovelock, J., 1991. Gaia: The practical science of planetary medicine (p. 14). London: Gaia Books.

28. Stead, W.E. and Garner Stead, J., 1994. Can humankind change the economic myth? Paradigm shifts necessary for ecologically sustainable business. Journal of Organizational Change Management, 7(4), pp.15-31

29. Lozano, R., 2014. Creativity and organizational learning as a means to foster sustainability. Sustainable development, 22(3), pp.205-216.

30. Mebratu, D., 1998. Sustainability and sustainable development: historical and conceptual review. Environmental impact assessment review, 18(6), pp.493-520.

31. Ringler, C., Bhaduri, A. and Lawford, R., 2013. The nexus across water, energy, land and food (WELF): potential for improved resource use efficiency?. Current Opinion in Environmental Sustainability, 5(6), pp.617-624.

32. Allan, T., Keulertz, M. and Woertz, E., 2015. The water-food-energy nexus: an introduction to nexus concepts and some conceptual and operational problems.

33. Leck, H., Conway, D., Bradshaw, M. and Rees, J., 2015. Tracing the water-energy-food nexus: Description, theory and practice. Geography Compass, 9(8), pp.445-460

34. Gain, A.K., Giupponi, C. and Benson, D., 2015. The water-energy-food (WEF) security nexus: the policy perspective of Bangladesh. Water International, 40(5-6), pp.895-910.

35. Pahl-Wostl, C., 2017. Governance of the water-energy-food security nexus: A multi-level coordination challenge. Environmental Science \& Policy.

36. Liu, J., Hull, V., Godfray, H.C.J., Tilman, D., Gleick, P., Hoff, H., Pahl-Wostl, C., Xu, Z., Chung, M.G., Sun, J. and Li, S., 2018. Nexus approaches to global sustainable development. Nature Sustainability, 1(9), pp.466-476.

37. Tosun, J. and Lang, A., 2017. Policy integration: mapping the different concepts. Policy Studies, 38(6), pp.553-570.

38. Griggs, D.J., Nilsson, M., Stevance, A. and McCollum, D., 2017. A guide to SDG interactions: from science to implementation. International Council for Science, Paris

39. Timko, J., Le Billon, P., Zerriffi, H., Honey-Rosés, J., de la Roche, I., Gaston, C., Sunderland, T.C. and Kozak, R.A., 2018. A policy nexus approach to forests and the SDGs: tradeoffs and synergies. Current opinion in environmental sustainability, 34, pp.7-12

40. Parida, P.K., Sustainable Development and Planning Process in India: A Public Policy Dimension. Indian Economy: Tales of Transformation, p.97.

41. Mukerji, A.K., 2018. The Impact of Multilateralism on India. Indian Foreign Affairs Journal, 13(4), pp.335-344.

42. Gogia, J. and Sikarwar, N., Agriculture and Dairy Sectors contribution to Food Security in India.

43. Lackey, R.T., 1998. Seven pillars of ecosystem management. Landscape and urban planning, 40(1-3), pp.21-30.

44. DeFries, R. and Nagendra, H., 2017. Ecosystem management as a wicked problem. Science, 356(6335), pp.265-270.

45. Asah, S.T., Guerry, A.D., Blahna, D.J. and Lawler, J.J., 2014 Perception, acquisition and use of ecosystem services: Human behavior, and ecosystem management and policy implications. Ecosystem Services, 10, pp.180-186.

46. Haeuber, R., 1998. Ecosystem management and environmental policy in the United States: open window or closed door?. Landscape and Urban Planning, 40(1-3), pp.221-233.

47. Kumar, S., Ugirashebuja, E., Carnwath, L., Tamminen, T. and Boyd, D., 2019. Environmental rule of law: First global report.

48. Raine, A. and Pluchon, E., 2019. UN Environment-Advancing the Environmental Rule of Law in the Asia Pacific. Chinese Journal of Environmental Law, 3(1), pp.117-126.

49. Ledoux, L., Crooks, S., Jordan, A. and Turner, R.K., 2000. Implementing EU biodiversity policy: UK experiences. Land use policy, 17(4), pp. 257-268.

50. MacDonald, K.I., 2010. The devil is in the (bio) diversity: Private sector "engagement" and the restructuring of biodiversity conservation. Antipode, 42(3), pp.513-550.

51. Young, J.C., Waylen, K.A., Sarkki, S., Albon, S., Bainbridge, I., Balian, E., Davidson, J., Edwards, D., Fairley, R., Margerison, C. and McCracken, D., 2014. Improving the science-policy dialogue to meet the challenges of biodiversity conservation: having conversations rather than talking at one-another. Biodiversity and Conservation, 23(2), pp.387-404

52. England, M.I., Dougill, A.J., Stringer, L.C., Vincent, K.E., Pardoe, J., Kalaba, F.K., Mkwambisi, D.D., Namaganda, E. and Afionis, S., 2018. Climate change adaptation and cross-sectoral policy coherence in southern Africa. Regional environmental change, 18(7), pp.2059-2071.

53. Cotton, D.R., Warren, M.F., Maiboroda, O. and Bailey, I., 2007. Sustainable development, higher education and pedagogy: a study of lecturers' beliefs and attitudes. Environmental Education Research, 13(5), pp.579-597.

54. Muff, K., Kapalka, A. and Dyllick, T., 2017. The Gap Frame-Translating the SDGs into relevant national grand challenges for strategic business opportunities. The International Journal of Management Education, 15(2), pp.363-383.

55. JADHAV, A., SAINI, P., RAVINDRA, A. and SINGH, S., 2019. Increasing forest or forest cover in India. CURRENT SCIENCE, 116(2), p.158.

56. Mall, R.K., Gupta, A., Singh, R., Singh, R.S. and Rathore, L.S., 2006 Water resources and climate change: An Indian perspective. Current science, pp.1610-1626

57. Abram, N.J., Gagan, M.K., Cole, J.E., Hantoro, W.S. and Mudelsee, M. 2008. Recent intensification of tropical climate variability in the Indian Ocean. Nature Geoscience, 1(12), p.849.

58. Sharmila, S., Joseph, S., Sahai, A.K., Abhilash, S. and Chattopadhyay, R., 2015. Future projection of Indian summer monsoon variability under climate change scenario: An assessment from CMIP5 climate models. Global and Planetary Change, 124, pp.62-78.

59. WATER, R., 2018. Education and Sustainability. ENSURE HEALTHY LIVES AND PROMOTE WELL-BEING FOR ALL, p.103.

60. Onial, M., Jasmine, B., Singh, Y., Pande, A., Ramesh, C., Sivakumar, K and Mathur, V.B., 2018. Updating India's National Biodiversity Action Plan: the process and way forward. CURRENT SCIENCE, 115(3), p.422.

61. JADHAV, A., SAINI, P., RAVINDRA, A. and SINGH, S., 2019. Increasing forest or forest cover in India. CURRENT SCIENCE, 116(2), p.158.

62. Percival, R.V., Schroeder, C.H., Miller, A.S and Leape, J.P., 2017. Environmental regulation: Law, science, and policy. Wolters Kluwer Law \& Business.

63. Tilak, J.B., 2018. Education poverty in India. In Education and Development in India (pp. 87-162). Palgrave Macmillan, Singapore.

64. Saidi, K. and Hammami, S., 2015. The impact of CO2 emissions and economic growth on energy consumption in 58 countries. Energy Reports, 1, pp.62-70.

65. Dey, J., Sakhre, S., Gupta, V., Vijay, R., Pathak, S., Biniwale, R. and Kumar, R., 2018. Geospatial assessment of tourism impact on land environment of Dehradun, Uttarakhand, India. Environmental monitoring and assessment, 190(4), p.181. 


\section{AUTHORS PROFILE}

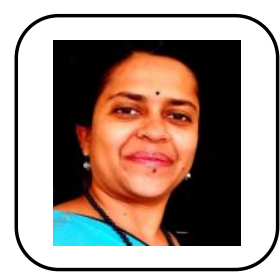

Gouri Shyam Joshi, Research Scholar, Bharati Vidyapeeth Institute of Environment Education and Research, Pune.

is a trained lawyer and freelance and in-house enviro-legal consultant with multiple consultancy organizations in Maharashtra. She has completed her Masters in Law from University of Pune and currently pursuing her Doctoral Research in Vidyapeeth (Deemed to be University). overlapping nature conservation laws from Bharati So far three papers have been published in a peer-reviewed journal, of which one is in Scopus indexed journal and one Chapter in a Book Edited by Dr R B Patil, University of Kolhapur.

She is a visiting lecturer for environmental laws of India, with various professional educational institutions under five Universities of Maharashtra and University of Cologne, Germany.

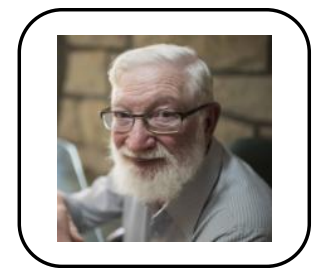

Dr Erach Bharucha, Director, Bharati Vidyapeeth Institute of Environment Education and Research, Pune.

Dr Erach Bharucha is a well-known surgeon in Pune, India for over 50 years. He has been active in wildlife conservation for four decades and has been a member on several central and state government committees. An environment educator at PG / UG / and school level he has an interest in Education for Sustainable Development. He has travelled and studied Indian national parks and wildlife sanctuaries extensively over the last four decades and has extensively photographed their ecosystem and species. His publications include 'Wonders of the Indian Wilderness' in three volumes. He has documented the cultural diversity of India, in the book 'Living Bridges' 2016, and India's cultural ecology in 'Changing Landscapes' 2017, published by Harper Collins. He has been a member of the Executive Committee of Bombay Natural History Society, and Governing Council of Salim Ali Centre for Ornithology and Natural History and Vice President of Wildlife Trust of India. In 1993, he initiated the Bharati Vidyapeeth Institute of Environment Education and Research (BVIEER), that runs M.Sc courses on Environment, Geoinformatics and Wildlife Conservation Action, where he continues as its present Director. Dr Bharucha has been associated with the NCERT, SCERT and UGC to further the cause of formal environmental education. He is the author of 'Textbook on Environmental Studies' for Undergraduate Courses (Published by University Press) which is used for the Core Module Course on Environment Studies now renamed Ability Enhancement Compulsory Course on Environmental Studies for all branches of Under Graduate courses. Dr Bharucha has been the Chairman of the Maharashtra State Biodiversity Board from 2012 to 2014. 